\title{
Purification and characterization of aminopeptidase A from Lactococcus lactis subsp. lactis NCDO 712
}

\author{
GORDON W. NivEN \\ AFRC Institute of Food Research, Reading Laboratory, Shinfield, Reading RG2 9AT, UK
}

(Received 5 December 1990; revised 1 February 1991; accepted 4 February 1991)

\begin{abstract}
An aminopeptidase A (EC 3.4.11.7) was purified from Lactococcus lactis subsp. lactis NCDO 712. Of the 18 aminoacyl-alanine dipeptides tested, the enzyme hydrolysed Asp-Ala, Glu-Ala and Ser-Ala. It was also active against tripeptide substrates but did not hydrolyse Ala-Asp or Ala-Glu. The kinetics of dipeptide hydrolysis were allosteric with positive cooperativity of substrate binding. The Hill constants were 1.52 for Asp-Ala, 1.51 for GluAla and 1.61 for Ser-Ala. The $M_{\mathrm{r}}$ was found to be $\mathbf{2 4 5 0 0 0}$ by gel-filtration chromatography. A single band corresponding to an $M_{\mathrm{r}}$ of 41000 was detected by SDS-PAGE of the purified enzyme which indicated that the enzyme is hexameric. Activity against glutamate $p$-nitroanilide was optimum at $65^{\circ} \mathrm{C}$ and $\mathrm{pH} 8$. Activity was inhibited by $1 \mathrm{mM}$-EDT A, implying that the enzyme is metal-containing. $\mathrm{Cu}^{2+}, \mathrm{Mn}^{2+}$ and $\mathrm{Zn}^{2+}$ (all at $1 \mathrm{mM}$ ) inhibited activity and $\mathrm{Co}^{2+}$ was stimulatory.
\end{abstract}

\section{Introduction}

Lactic acid bacteria are widely used as starter cultures in the manufacture of cheese, where they are involved not only in the initial fermentation of lactose but also in subsequent flavour development. Amino nitrogen in milk is available mainly in the form of proteins and lactic acid bacteria possess a wide array of proteolytic and peptidolytic enzymes in order to utilize this source of nitrogen (Thomas \& Mills, 1981; Law \& Kolstad, 1983). The activity of these enzymes over several months, even after cessation of active cell growth, contributes to the development of the flavour of mature cheese (Grappin et al., 1984; Rank et al., 1984; Kamaly \& Marth, 1989), and the addition of extracts of starter cultures during cheese manufacture accelerates cheese ripening (Law \& Wigmore, 1983).

The purification and characterization of peptidolytic enzymes is fundamental to the understanding of starter culture nutrition and the improvement of starter culture strains. Several such enzymes have been purified from strains of Lactococcus lactis subsp. cremoris (formerly Streptococcus cremoris) including an aminopeptidase A (Exterkate \& De Veer, 1987), a dipeptidase (Van Boven et al., 1988), a tripeptidase (Bosman et al., 1990), a

Abbreviation: GNA, L-glutamate p-nitroanilide.
$\mathrm{X}$-prolyl dipeptidyl aminopeptidase (Kiefer-Partsch et al., 1989; Booth et al., 1990) and aminopeptidases with activity against a wide range of dipeptides and tripeptides (Neviani et al., 1989; Tan \& Konings, 1990). In the case of Lactococcus lactis subsp. lactis (formerly Streptococcus lactis), only a X-prolyl dipeptidyl aminopeptidase has been purified and characterized (Zevaco et al., 1990; Lloyd \& Pritchard, 1991), although this subspecies is also widely used in cheese manufacture.

Using cluster analysis, Kaminogawa et al. (1983) demonstrated that cremoris and lactis subspecies of $L$. lactis formed distinct groups on the basis of peptidase activities against 54 substrates, including 10 different $\mathrm{N}$ terminal amino acid residues. The elution profiles of peptidase activities on ion-exchange chromatography were different between these groups. It is therefore possible that there are significant differences in the characters and types of these enzymes between subspecies which contribute to their different cheese making properties. Further studies of the enzymes of $L$. lactis subsp. lactis are required if an adequate comparison is to be made.

In this paper the purification and characterization of a peptidase from L. lactis subsp. lactis is described; this enzyme shows specific activity against acidic $\mathrm{N}$-terminal amino acid residues (aminopeptidase $\mathrm{A}$, EC 3.4.11.7). 
Table 1. Purification of aminopeptidase A from L. lactis subsp. lactis NCDO 712

The data shown are the results of a single purification but are typical of several similar purifications.

\begin{tabular}{lccccc}
\hline \hline \multicolumn{1}{c}{$\begin{array}{c}\text { Purification } \\
\text { step }\end{array}$} & $\begin{array}{c}\text { Total } \\
\text { protein } \\
(\mathrm{mg})\end{array}$ & $\begin{array}{c}\text { Total } \\
\text { activity } \\
(\mathrm{U})\end{array}$ & $\begin{array}{c}\text { Specific } \\
\text { activity } \\
\left(\mathrm{U} \mathrm{mg} \mathrm{m}^{-1}\right)\end{array}$ & $\begin{array}{c}\text { Purification } \\
(- \text { fold })\end{array}$ & $\begin{array}{c}\text { Yield } \\
(\%)\end{array}$ \\
\hline Cell-free extract & 1076 & $10 \cdot 45$ & $0 \cdot 0097$ & $1 \cdot 0$ & 100 \\
Heat treatment & 264 & $9 \cdot 20$ & $0 \cdot 0349$ & $3 \cdot 6$ & 88 \\
Ammonium sulphate precipitation & $50 \cdot 4$ & $6 \cdot 29$ & $0 \cdot 125$ & $12 \cdot 8$ & 60 \\
Phenyl-Sepharose & $3 \cdot 25$ & $5 \cdot 64$ & $1 \cdot 73$ & 178 & 54 \\
Mono Q & $0 \cdot 595$ & $4 \cdot 20$ & $7 \cdot 06$ & 727 & 40 \\
\hline \hline
\end{tabular}

\section{Methods}

Organism and preparation of cell extracts. Lactococcus lactis subsp. lactis NCDO 712 [obtained from the National Collection of Dairy Organisms (now the National Collection of Food Bacteria, NCFB), Shinfield, Reading, UK] was grown in 101 batch cultures of M17 broth (Difco) containing $5 \mathrm{~g}$ lactose $\mathrm{l}^{-1}$. These were inoculated to $15 \%(\mathrm{v} / \mathrm{v})$ and incubated for $4 \mathrm{~h}$ at $30^{\circ} \mathrm{C}$ prior to harvesting

Cultures were washed in $50 \mathrm{~mm}$-Tris/ $\mathrm{HCl}, \mathrm{pH} 7 \cdot 5$, and concentrated to approximately $150 \mathrm{ml}$ by cross-flow filtration using a Millipore Pellicon system fitted with a $0.45 \mu \mathrm{m}$ membrane. Cells were disrupted by two passes through a French pressure cell at $100 \mathrm{MPa}$ and debris was removed by centrifugation at $20000 \mathrm{~g}$ for $30 \mathrm{~min}$.

Assay of aminopeptidase $A$ activity. Activity was determined by measuring the formation of $p$-nitroanilide at $50^{\circ} \mathrm{C}$ in a $1 \mathrm{ml}$ reaction mixture containing $1 \mathrm{mM}$-L-glutamate $p$-nitroanilide (GNA) (Bachem Feinchemikalien), $50 \mathrm{~mm}$-Tris $/ \mathrm{HCl}, \mathrm{pH} 8.0$, and $50 \mu \mathrm{l}$ of enzyme solution. Samples were incubated for 10-20 min, over which time the reaction rate was linear. The reaction was stopped by the addition of $0.5 \mathrm{ml} \mathrm{30 \%} \% \mathrm{v} / \mathrm{v})$ acetic acid and samples were centrifuged for $15 \mathrm{~min}$ at $10000 \mathrm{~g}$. Absorbance at $410 \mathrm{~nm}$ was measured and $p$-nitroanilide concentration was determined using a molar absorption coefficient of $8800 \mathrm{M}^{-1} \mathrm{~cm}^{-1}$. All assays were done in duplicate and the mean variation between samples was approximately $4 \%$. One unit of activity was defined as the amount of enzyme required to produce $1 \mu \mathrm{mol} p$ nitroanilide in 1 min under the conditions described above.

Purification of aminopeptidase A. Approximately $150 \mathrm{ml}$ of cell-free extract was incubated in a waterbath at $60^{\circ} \mathrm{C}$ for $30 \mathrm{~min}$ with constant stirring. It was then cooled to $4{ }^{\circ} \mathrm{C}$ and centrifuged at $20000 \mathrm{~g}$ for $30 \mathrm{~min}$.

The supernatant was subject to precipitation by the addition of solid $\left(\mathrm{NH}_{4}\right)_{2} \mathrm{SO}_{4}$ at $4{ }^{\circ} \mathrm{C}$. Proteins precipitating between $20 \%$ and $40 \%$ saturation were collected by centrifugation at $10000 \mathrm{~g}$ for $30 \mathrm{~min}$ and the pellet was resuspended in $0.5 \mathrm{M}-\left(\mathrm{NH}_{4}\right)_{2} \mathrm{SO}_{4}$ in $50 \mathrm{~mm}-\mathrm{Tris} / \mathrm{HCl}$, $\mathrm{pH} 7 \cdot 5$.

Hydrophobic interaction chromatography of the resuspended precipitate was carried out using a $22 \times 1.5 \mathrm{~cm}$ phenyl-Sepharose column (Pharmacia). A gradient of $0.5 \mathrm{M}$ to $0 \mathrm{M}-\left(\mathrm{NH}_{4}\right)_{2} \mathrm{SO}_{4}$ in $50 \mathrm{~mm}$ Tris/ $\mathrm{HCl}, \mathrm{pH} 7 \cdot 5$, was run over $200 \mathrm{ml}$ at $1 \mathrm{ml} \mathrm{min}{ }^{-1}$. Eluent fractions containing aminopeptidase $\mathrm{A}$ activity were pooled and dialysed against $50 \mathrm{~mm}$-Tris/ $\mathrm{HCl}, \mathrm{pH} 7 \cdot 5$.

The dialysate was applied to a Pharmacia HR 5/5 Mono Q anionexchange column. A gradient of $0 \mathrm{M}$ to $0.5 \mathrm{M}-\mathrm{NaCl}$ in $50 \mathrm{~mm}-\mathrm{Tris} / \mathrm{HCl}$, $\mathrm{pH} 7.5$, was run over $25 \mathrm{ml}$ at $0.5 \mathrm{ml} \mathrm{min}^{-1}$. Collected fractions which contained aminopeptidase $\mathrm{A}$ activity were pooled and dialysed against $50 \mathrm{~mm}$-Tris/ $\mathrm{HCl}, \mathrm{pH} 7 \cdot 5$.

$M_{\mathrm{r}}$ determination. The $M_{\mathrm{r}}$ of purified native enzyme was determined by gel filtration using a Pharmacia HR 10/30 Superose 12 column.
Samples $(100 \mu \mathrm{l})$ containing $10-20 \mu \mathrm{g}$ protein were loaded and eluted at $0.4 \mathrm{ml} \mathrm{min} \mathrm{m}^{-1}$ of $50 \mathrm{~mm}-\mathrm{Tris} / \mathrm{HCl}, \mathrm{pH} 7.5$, containing $100 \mathrm{mM}-\mathrm{NaCl}$. The column was calibrated using the following Sigma $M_{\mathrm{r}}$ standards: lysozyme, myoglobin, $\beta$-lactoglobulin, bovine serum albumin, alcohol dehydrogenase and $\beta$-amylase.

Subunit $M_{\mathrm{r}}$ was determined by SDS-PAGE using a Pharmacia Phast System. Samples $(3 \mu \mathrm{l})$ containing $0.3 \mu \mathrm{g}$ protein were run on $20 \%$ homogeneous gels for $100 \mathrm{~V} \mathrm{~h}$ at $15^{\circ} \mathrm{C}$. Gels were stained using the Pharmacia silver staining kit by the manufacturer's recommended procedure.

Hydrolysis of dipeptides. The hydrolysis of alanine-containing dipeptides was determined at $25^{\circ} \mathrm{C}$ in a coupled assay with alanine dehydrogenase (EC 1.4.1.1). The formation of NADH was constantly monitored at $340 \mathrm{~nm}$ in a reaction mixture containing $1 \mathrm{U}$ alanine dehydrogenase $\mathrm{ml}^{-1}, 2 \mathrm{~mm}-\mathrm{NAD}^{+}, 1 \mathrm{~mm}$-dipeptide and $2 \mathrm{mU}$ purified aminopeptidase $\mathrm{A} \mathrm{ml} \mathrm{ml}^{-1}$ in $50 \mathrm{~mm}$-Tris/ $\mathrm{HCl}, \mathrm{pH} 8.0$. The rate of NADH formation was calculated using a molar absorption coefficient of $6220 \mathrm{M}^{-1} \mathrm{~cm}^{-1}$. Control assays containing no enzyme were also carried out and the rate of NADH formation for each substrate was subtracted from that in the presence of enzyme. The mean variation between duplicate samples was $1.5 \%$.

Hydrolysis of tripeptides. Samples $(1 \mathrm{ml})$ containing $0.4 \mathrm{~mm}$-tripeptide and $2 \mathrm{mU}$ purified aminopeptidase $\mathrm{ml}^{-1}$ in $50 \mathrm{~mm}-\mathrm{Tris} / \mathrm{HCl}, \mathrm{pH} 8$, were incubated for $60 \mathrm{~min}$ at $50^{\circ} \mathrm{C}$. After this time the reaction was terminated by the addition of $0.5 \mathrm{ml} 30 \%(\mathrm{v} / \mathrm{v})$ acetic acid and samples were centrifuged for $15 \mathrm{~min}$ at $10000 \mathrm{~g}$. Control samples which contained no enzyme were incubated in the same way. Tripeptide hydrolysis was determined by capillary electrophoresis using an Applied Biosystems 270A system and a Drew Scientific Roseate data collection and integration package. Samples were loaded for $3 \mathrm{~s}$ under vacuum and run for $10 \mathrm{~min}$ in $20 \mathrm{~mm}$-sodium citrate buffer, $\mathrm{pH} 2.5$, at $45^{\circ} \mathrm{C}$ with a positive potential of $30 \mathrm{kV}$. Eluent absorbance was constantly monitored at $200 \mathrm{~nm}$.

Protein determination. Protein concentrations were determined by the method of Bradford (1976).

\section{Results}

An enzyme which was capable of hydrolysing GNA was detected in cell-free extracts of $L$. lactis subsp. lactis and was purified to homogeneity by the method described above. The results of each step of a typical purification are shown in Table 1. The enzyme eluted from the phenyl-Sepharose column at approximately $0.18 \mathrm{M}$ $\left(\mathrm{NH}_{4}\right)_{2} \mathrm{SO}_{4}$ which implies a high degree of hydrophobi- 
Table 2. Hydrolysis of dipeptides by aminopeptidase $A$

Liberation of alanine was detected via the synthesis of NADH by alanine dehydrogenase. Each assay contained $1 \mathrm{mM}$-dipeptide and $2 \mathrm{mU}$ purified aminopeptidase $\mathrm{A} \mathrm{ml}^{-1}$.

\begin{tabular}{lccc}
\hline \hline Substrate & $\begin{array}{c}\text { NADH produced } \\
\left(\mathrm{nmol} \mathrm{min}^{-1} \mathrm{ml}^{-1}\right)\end{array}$ & Substrate & $\begin{array}{c}\text { NADH produced } \\
\left(\mathrm{nmol} \mathrm{min} \mathrm{ml}^{-1}\right)\end{array}$ \\
\hline Ala-Ala & $0.346^{*}$ & Met-Ala & 0.068 \\
Arg-Ala & 0.116 & Phe-Ala & 0.077 \\
Asp-Ala & 6.482 & Pro-Ala & 0.000 \\
Cys-Ala & $0 \cdot 154$ & Ser-Ala & 2.691 \\
Glu-Ala & $8 \cdot 740$ & Thr-Ala & 0.048 \\
Gly-Ala & $0 \cdot 125$ & Trp-Ala & 0.135 \\
His-Ala & 0.087 & Tyr-Ala & 0.174 \\
Ile-Ala & $0 \cdot 164$ & Val-Ala & $0 \cdot 125$ \\
Leu-Ala & $0 \cdot 145$ & Ala-Asp & 0.010 \\
Lys-Ala & 0.125 & Ala-Glu & 0.277 \\
\hline \hline
\end{tabular}

* The actual rate of Ala-Ala hydrolysis was half that of NADH formation due to the formation of $2 \mathrm{~mol}$ alanine per mol of dipeptide hydrolysed.

city. A $\mathrm{NaCl}$ concentration of $0.3 \mathrm{M}$ was required to elute the enzyme from the Mono $Q$ ion-exchange column. The resulting eluent gave a single band on SDS-PAGE corresponding to an $M_{\mathrm{r}}$ of 41000 . The $M_{\mathrm{r}}$ of the native enzyme as determined by gel-filtration chromatography on Superose 12 was 245000 . These data are consistent with the enzyme being a hexamer of identical subunits.

Substrate specificity of the purified enzyme was investigated by determining the rate of hydrolysis of a series of alanine-containing dipeptides in a coupled assay with alanine dehydrogenase (Table 2). Of the 18 aminoacyl-alanine dipeptides tested, only Asp-Ala, GluAla and Ser-Ala were hydrolysed to a significant extent. The rates of hydrolysis of all other aminoacyl-alanine dipeptides were less than $2 \%$ of the rate of hydrolysis of Glu-Ala. No significant hydrolysis of Ala-Glu or AlaAsp was observed which indicates that this enzyme is not capable of hydrolysing acidic C-terminal amino acid residues. The purified enzyme was also active against tripeptide substrates. Samples of Glu-Glu-Glu, Glu-GluAsp and Glu-Val-Phe were analysed by capillary electrophoresis after incubation for $60 \mathrm{~min}$ in the presence and in the absence of aminopeptidase (Table 3). In this time Glu-Glu-Glu was completely hydrolysed and no dipeptide peak was detected. Glu-Glu-Asp was partially hydrolysed and $20 \%$ of the substrate remained after incubation in the presence of the enzyme. A single product peak was also detected which possibly corresponded to Glu-Asp although this peak was small and it is likely that most of the dimer product was further hydrolysed to single amino acids. Glu-Val-Phe was also completely hydrolysed and a single product peak which accounted for approximately all of the substrate was detected. It is therefore likely that the enzyme cleaved the $\mathrm{N}$-terminal glutamate residue, leaving Val-Phe

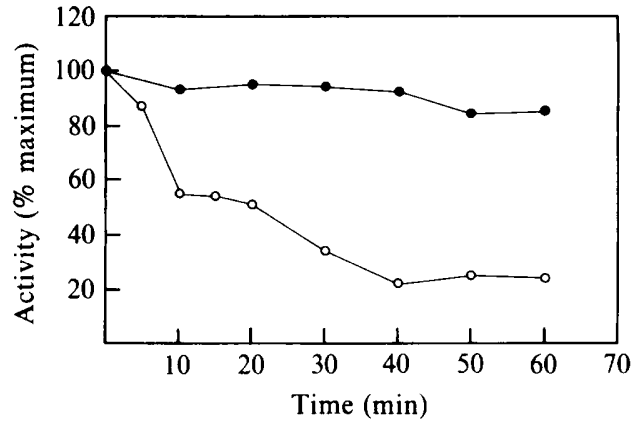

Fig. 1. The thermal stability of aminopeptidase A. Samples containing $4 \mathrm{mU}$ purified enzyme $\mathrm{ml}^{-1}$ in $50 \mathrm{~mm}$-Tris/ $\mathrm{HCl}$ buffer, $\mathrm{pH} 8$, were preincubated at $70^{\circ} \mathrm{C}(\mathrm{O})$ and $80^{\circ} \mathrm{C}(\mathrm{O})$ prior to assaying at $50^{\circ} \mathrm{C}$ using GNA as substrate

which was not hydrolysed further. This spectrum of activity is consistent with the designation of the enzyme an aminopeptidase A (EC 3.4.11.7).

The effects of $\mathrm{pH}$ and temperature on the activity of the purified enzyme were investigated using GNA as substrate. Activity optima were at approximately $\mathrm{pH} 8$ and $65^{\circ} \mathrm{C}$. The enzyme also showed a high degree of thermal stability. Samples were preincubated for varying times in waterbaths at $70^{\circ} \mathrm{C}$ and $80^{\circ} \mathrm{C}$. Activity was assayed after rapid cooling of samples in iced water followed by equilibration at $50{ }^{\circ} \mathrm{C}: 85 \%$ of activity remained after preincubation for $60 \mathrm{~min}$ at $70{ }^{\circ} \mathrm{C}$ and $24 \%$ remained after preincubation for the same time at $80^{\circ} \mathrm{C}$ (Fig. 1). The thermal stability of the enzyme was made use of as part of the purification procedure described previously. The purified enzyme was stored at $4{ }^{\circ} \mathrm{C}$ in $50 \mathrm{~mm}$-Tris/ $\mathrm{HCl}, \mathrm{pH} \mathrm{7.5}$, and showed no appreciable loss of activity after 3 months under these conditions.

The activity of aminopeptidase A was determined in the presence of various compounds which are known to

\section{Table 3. Hydrolysis of tripeptides by aminopeptidase $A$}

Samples containing $0.4 \mathrm{~mm}$-tripeptides were incubated for $60 \mathrm{~min}$ at $50^{\circ} \mathrm{C}$ in the presence of $2 \mathrm{mU}$ purified aminopeptidase $\mathrm{A} \mathrm{ml}^{-1}$ and in the absence of enzyme. Samples were analysed by capillary electrophoresis. These data are the result of a single experiment but are representative of several replicate analyses.

\begin{tabular}{|c|c|c|c|c|}
\hline \multirow[b]{3}{*}{ Substrate } & \multicolumn{4}{|c|}{ Peaks detected } \\
\hline & \multicolumn{2}{|c|}{ - Enzyme } & \multicolumn{2}{|c|}{ +Enzyme } \\
\hline & $\begin{array}{l}\text { Retention time } \\
(\mathrm{min})\end{array}$ & $\begin{array}{c}\text { Area } \\
\text { (units) }\end{array}$ & $\begin{array}{l}\text { Retention time } \\
(\min )\end{array}$ & $\begin{array}{c}\text { Area } \\
\text { (units) }\end{array}$ \\
\hline Glu-Glu-Asp & $7 \cdot 52$ & $58 \cdot 8$ & $\begin{array}{l}7 \cdot 50 \\
6 \cdot 85\end{array}$ & $\begin{array}{r}13 \cdot 16 \\
8 \cdot 70\end{array}$ \\
\hline Glu-Glu-Glu & $7 \cdot 35$ & $55 \cdot 2$ & - & - \\
\hline Glu-Val-Phe & $6 \cdot 84$ & 202 & $6 \cdot 08$ & 189 \\
\hline
\end{tabular}


Table 4. Effects of enzyme inhibitors on aminopeptidase $A$ activity

Activities were determined using GNA as substrate with $2 \mathrm{mU}$ purified enzyme $\mathrm{ml}^{-1}$ and $1 \mathrm{mM}$ inhibitor.

\begin{tabular}{lc}
\hline \hline \multicolumn{1}{c}{ Inhibitor } & $\begin{array}{c}\text { Activity } \\
(\% \text { control })\end{array}$ \\
\hline None & 100 \\
EDTA & 14 \\
Iodoacetamide & 98 \\
Iodoacetic acid & 98 \\
Phenylmethylsulphonyl fluoride & 111 \\
Leucine chloromethylketone & 104 \\
\hline \hline
\end{tabular}

inhibit certain types of enzymes (Table 4). The inclusion of $1 \mathrm{~mm}$-EDTA in the assay resulted in a substantial inhibition of activity which implied that the enzyme may be metal-cortaining. None of the other compounds which were tested, including the sulphydryl reagents iodoacetamide and iodoacetic acid, the serine protease inhibitor phenylmethylsulphonyl fluoride and the leucine aminopeptidase inhibitor leucine chloromethylketone had any inhibitory effect.

The effects of metal salts on enzyme activity are shown in Table 5. Aminopeptidase A was strongly inhibited by $1 \mathrm{mM}-\mathrm{Cu}^{2+}$ and, to a lesser extent by $1 \mathrm{mM}-\mathrm{Mn}^{2+}$ and $\mathrm{Zn}^{2+} . \mathrm{Co}^{2+}$ had a stimulatory effect on enzyme activity.

A study of the effect of substrate concentration on enzyme activity using Glu-Ala, Asp-Ala and Ser-Ala substrates revealed allosteric kinetics. Fig. 2 shows Hill plots for each substrate and the kinetic parameters, which were determined using the Enzfitter data analyses computer program (Elsevier-Biosoft), are listed in Table 6 . The gradients of each line are similar and are greater than 1 which indicates positive cooperativity of substrate binding. The cooperativity indices (Taketa \& Pogel, 1965) of this enzyme were calculated to be 18 for Glu-Ala and Asp-Ala and 15 for Ser-Ala, compared with a theoretical value of 81 for Michaelis-Menten kinetics.

Table 5. Effect of metal salts on the activity of aminopeptidase $A$

Activities were determined using GNA as substrate with $2 \mathrm{mU}$ purified enzyme $\mathrm{ml}^{-1}$ and $1 \mathrm{mM}$ salts.

\begin{tabular}{lclr}
\hline \hline Addition & $\begin{array}{c}\text { Activity } \\
\text { (\% control) }\end{array}$ & Addition & $\begin{array}{c}\text { Activity } \\
\text { (\% control) }\end{array}$ \\
\hline None & 100 & $\mathrm{MnCl}_{2}$ & 46 \\
$\mathrm{CaCl}_{2}$ & 106 & $\mathrm{NaCl}_{2}$ & 126 \\
$\mathrm{CoCl}_{2}$ & 143 & $\mathrm{Na}_{2} \mathrm{SO}_{4}$ & 121 \\
$\mathrm{CuSO}_{4}$ & 7 & $\mathrm{ZnSO}_{4}$ & 39 \\
$\mathrm{MgCl}_{2}$ & 112 & & \\
\hline \hline
\end{tabular}

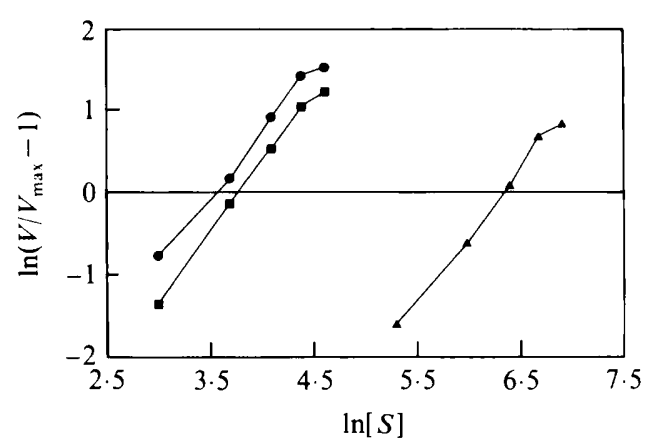

Fig. 2. Hill plots of aminopeptidase A activity against substrate concentration. The units of substrate concentration $([S])$ are $\mu \mathrm{M}$ and the units of enzyme activity $(V)$ are $\mathrm{mU} \mathrm{min}^{-1}(\mathrm{mg} \text { protein })^{-1}$. The substrates used were Asp-Ala (O), Glu-Ala $(\boldsymbol{\square})$ and Ser-Ala (A). Activities were determined by monitoring the formation of NADH in a coupled assay with alanine dehydrogenase.

Table 6. Kinetic parameters of aminopeptidase $A$

These data are derived from the plots shown in Fig. 2. Activities were determined by measuring the rate of NADH formation in a coupled assay with alanine dehydrogenase.

\begin{tabular}{lccc}
\hline \hline Substrate & $\begin{array}{c}V_{\max } \\
{\left[\mu \mathrm{mol} \mathrm{min}^{-1}\right.} \\
\left.(\mathrm{mg} \text { protein })^{-1}\right]\end{array}$ & $\begin{array}{c}K_{\mathrm{m}} \\
(\mathrm{mM})\end{array}$ & $\begin{array}{c}\text { Hill } \\
\text { constant }\end{array}$ \\
\hline Asp-Ala & 36.3 & 0.212 & 1.52 \\
Glu-Ala & 42.6 & 0.283 & 1.51 \\
Ser-Ala & 11.9 & 27.3 & 1.61 \\
\hline \hline
\end{tabular}

The values of $V_{\max }$ and $K_{\mathrm{m}}$ for Glu-Ala and Asp-Ala were similar but the $V_{\max }$ of Ser-Ala was lower and the value of $K_{\mathrm{m}}$ was higher. The affinity of the enzyme for Ser-Ala and its ability to hydrolyse this substrate were significantly lower than for Glu-Ala or Asp-Ala.

\section{Discussion}

The enzymes forming the peptidolytic system of $L$. lactis have been most thoroughly studied in strains of $L$. lactis subsp. cremoris. The only aminopeptidase previously purified from $L$. lactis subsp. lactis was a X-prolyl dipeptidyl aminopeptidase (Zevaco et al., 1990; Lloyd \& Pritchard, 1991). The purification and characterization of an acidic aminopeptidase from that subspecies is described in this report. The purification procedure described made use of the high thermal stability and hydrophobicity of the enzyme and resulted in a 700 -fold purification and a recovery of $40 \%$.

The substrate specificity of this enzyme was tested against a substantial range of aminoacyl-alanine dipeptides, and the enzyme was shown to be active against $\mathrm{N}$ terminal aspartyl and glutamyl residues. It was also 
active against tripeptide substrates but did not cleave acidic C-terminal residues. It was therefore designated as an aminopeptidase $\mathrm{A}$ (EC 3.4.11.7). In addition, this enzyme also hydrolysed seryl-alanine. An aminopeptidase A has previously been purified from L. lactis subsp. cremoris (Exterkate \& De Veer, 1987) but activity against seryl residues was not reported; nor has this activity been observed in aminopeptidase A purified from mammalian sources (Nagatsu et al., 1970; Danielsen et al., 1980; Benajiba \& Maroux, 1980; Tobe et al., 1980). Many of the serine residues in caseins are phosphorylated (Eigel et al., 1984) but it is possible that this enzyme may have activity against phosphorylated serine residues if the acidic side chain causes them to act as aspartate analogues. This activity may therefore be of importance in the utilization of casein-derived peptides by lactic acid bacteria. Further work is in progress to investigate this hypothesis.

The aminopeptidase A purified from L. lactis subsp. cremoris by Exterkate \& De Veer (1987) was reported to be a trimer of $M_{\mathrm{r}} 130000$ compared to the $M_{\mathrm{r}} 245000$ hexamer described here. However, both enzymes showed a high degree of thermal stability, were metalloproteins and had similar subunit $M_{\mathrm{r}}$ values. Kaminogawa et al. (1983) studied the spectrum of peptidase activities in extracts of 11 strains of $S$. lactis and $S$. cremoris after ion-exchange chromatography using 54 different substrates. They showed that the strains investigated could be divided into three groups on this basis which differentiated between cremoris and lactis strains. Kolstad \& Law (1985) demonstrated differing spectra of peptidase activities between $S$. lactis and $S$. cremoris using electrophoretic separation. S. lactis and $S$. cremoris have been shown to have a high degree of DNA homology (Jarvis \& Jarvis, 1981) and have since been removed from the genus Streptococcus and reclassified as subspecies of Lactococcus lactis (Schleifer et al., 1985). Despite the broad similarities between these strains, there are therefore specific differences in their peptidolytic enzymes which may have some significance for their use in the dairy industry. Further studies, particularly of the enzymes from $L$. lactis subsp. lactis, are required to determine the influence of such differences on the use of these strains in cheese starter cultures.

In this report, allosteric kinetics for the hydrolysis of dipeptides by aminopeptidase A were observed which indicated a degree of positive cooperativity of substrate binding. Studies have been made of the kinetics of action of peptidases from $L$. lactis subsp. cremoris against aminoacyl $p$-nitroanilide substrates (Neviani et al., 1989; Tan \& Konings, 1990) and peptide substrates (Van Boven et al., 1988; Bosman et al., 1990) and in each case Michaelis-Menten saturation kinetics were described.

There is a great deal of interest in the peptidolytic systems of lactic acid bacteria because of their suspected role in the development of cheese flavour (Law \& Wigmore, 1983). Aminopeptidase A may be significant in this respect as glutamate salts have flavour-enhancing properties (Kirimura et al., 1969) and this enzyme has high stability and substrate affinity. It may be possible to improve strains of starter bacteria by cloning and controlling the expression of such enzymes.

The author is grateful to Dr Nigel Turner for carrying out SDSPAGE of the purified enzyme and to Drs Fran Mulholland, Tony Andrews and Barry Law for constructive discussions.

\section{References}

Benajiba, A. \& Maroux, S. (1980). Purification and characterization of an aminopeptidase $A$ from hog intestinal brush-border membrane. European Journal of Biochemistry 107, 381-388.

Booth, M., Fhaoláin, I. N., Jennings, P. V. \& O'Cuinn, G. (1990) Purification and characterization of a post-proline dipeptidyl aminopeptidase from Streptococcus cremoris AM2. Journal of Dairy Research 57, 89-99.

Bosman, B. W., Tan, P. S. T. \& Konings, W. N. (1990). Purification and characterization of a tripeptidase from Lactococcus lactis subsp. cremoris Wg2. Applied and Environmental Microbiology 56, 1839 1843.

BRADFORD, M. M. (1976). A rapid and sensitive method for the quantitation of microgram quantities of protein utilizing the principle of protein-dye binding. Analytical Biochemistry 72, 248 254.

Danielsen, E. M., Norén, O., Suöström, H., Ingram, J. \& KenNey, A. J. (1980). Aspartate aminopeptidase: purification by immunoadsorbent chromatography and properties of the detergent- and proteinase-solubilized forms. Biochemical Journal 189, 591-603.

Eigel, W. N., Butler, J. E., Ernstrom, C. A., Farrell, H. M., Harwalkar, V. R., JenNess, R. \& Whitney, R. M. (1984). Nomenclature of proteins of cow's milk: fifth revision. Journal of Dairy Science 67, 1599-1631.

Exterkate, F. A. \& De Veer, G. J. C. M. (1987). Purification and some properties of a membrane-bound aminopeptidase A from Streptococcus cremoris. Applied and Environmental Microbiology 53, $577-583$.

Grappin, R., Rank, T. C. \& Olson, N. F. (1984). Primary proteolysis of cheese proteins during ripening. A review. Journal of Dairy Science 68, 531-540.

JARVIS, A. W. \& JARVIS, B. D. W. (1981). Deoxyribonucleic acid homology among lactic Streptococci. Applied and Environmental Microbiology 41, 77-83.

Kamaly, K. M. \& Marth, E. H. (1989). Enzyme activities of lactic streptococci and their role in the maturation of cheese: a review. Journal of Dairy Science 72, 1945-1966.

Kaminogawa, S., Ninomiya, T. \& Yamauch, K. (1983). Aminopeptidase profiles of lactic streptococci. Journal of Dairy Science 67, 24832492.

Kiefer-Partsch, B., BockelmanN, W., Geis, A. \& Teuber, M. (1989). Purification of an X-prolyl-dipeptidyl aminopeptidase from the cell wall proteolytic system of Lactococcus lactis subsp. cremoris. Applied Microbiology and Biotechnology 31, 75-78.

Kirimura, J., Shimizu, A., KimizuKa, A., Ninomiya, T. \& Katsuya, N. (1969). The contribution of peptides and amino acids to the taste of foodstuffs. Journal of Agricultural and Food Chemistry 17, 689-695.

KolsTAD, J. \& LAW, B. A. (1985). Comparative peptide specificity of cell wall, membrane and intracellular peptidases of group $\mathrm{N}$ streptococci. Journal of Applied Bacteriology 58, 449-456.

LAW, B. A. \& Kolstad J. (1983). Proteolytic systems in lactic acid bacteria. Antonie van Leeuwenhoek 49, 225-245. 
LAW, B. A. \& Wigmore, A. S. (1983). Accelerated ripening of cheddar cheese with a commercial proteinase and intracellular enzymes from starter streptococci. Journal of Dairy Research 50, 519-525.

LLOYD, R. J. \& PRITCHARD, G. G. (1991). Characterization of X-prolyl dipeptidyl aminopeptidase from Lactococcus lactis subsp. lactis. Journal of General Microbiology 137, 49-55.

Nagatsu, I., Nagatsu, T., Yamamoto, T., Glenner, G. G. \& Mehl, J. W. (1970). Purification of aminopeptidase $A$ in human serum and degradation of angiotensin II by the purified enzyme. Biochimica et Biophysica Acta 198, 255-270.

Neviani, E., Boquien, C. Y., Monnet, V., Thanh, L. P. \& Gripon, J.-C. (1989). Purification and characterization of an aminopeptidase from Lactococcus lactis subsp. cremoris AM2. Applied and Environmental Microbiology 55, 2308-2314.

Rank, T. C., Grappin, R. \& Olson, N. F. (1984). Secondary proteolysis during cheese ripening: a review. Journal of Dairy Science 68, 801-805.

Schleifer, K. H., Kraus, J., Dvorak, C., Kilpper-Balz, R., Collins, M. D. \& Fischer, W. (1985). Transfer of Streptococcus lactis and related Streptococci to the genus Lactococcus gen. nov. Systematic and Applied Microbiology 6, 183-195.
Taketa, K. \& Pogel, B. M. (1965). Allosteric inhibition of rat liver fructose 1,6-diphosphatase by adenosine $5^{\prime}$-monophosphate. Journal of Biological Chemistry 240, 651-662.

TAN, P. S. T. \& KonINGS, W. N. (1990). Purification and characterization of an aminopeptidase from Lactococcus lactis subsp. cremoris Wg2. Applied and Environmental Microbiology 56, 526-532.

Thomas, T. D. \& Mills, O. E. (1981). Proteolytic enzymes of starter bacteria. Netherlands Milk and Dairy Journal 35, 255-273.

Tobe, H., Kojima, F., Aoyagi, T. \& Umezawa, H. (1980). Purification by affinity chromatography using amastatin and properties of aminopeptidase A from pig kidney. Biochimica et Biophysica Acta 613, 459-468.

Van Boven, A., TAN, P. S. T. \& Konings, W. N. (1988). Purification and characterization of a dipeptidase from Streptococcus cremoris Wg2. Applied and Environmental Microbiology 54, 43-49.

ZeVACo, C., MONNET, V. \& GRIPON, J.-C. (1990). Intracellular X-prolyl dipeptidyl aminopeptidase from Lactococcus lactis ssp. lactis: purification and properties. Journal of Applied Bacteriology 68, 357366. 